\title{
Peninsular Lessons for Atoll Warfare: The U.S. Marine Corps and the Development of Naval Gunfire Doctrine
}

\author{
By Paul J. Cook
}

\begin{abstract}
This paper utilizes the 1943 Battle of Tarawa as a lens to examine and evaluate the influence of the ill-fated Gallipoli campaign of 1915 upon U.S. Marine Corps inter-war development of naval gunfire support doctrine within amphibious warfare planning and the effectiveness of those plans in combat operations during Operation GALVANIC. The lessons of Gallipoli, specifically those that relate to the employment of naval gunfire, were key pieces of American pre-war planning, and yet, they underwent considerable revision once the war began. Tarawa served as a platform upon which inter-war ideas of amphibious operations were tested and their results adapted or modified in preparation for subsequent amphibious operations against Japanese holdings in the Pacific. American victory at Tarawa validated American amphibious warfare doctrine. Inter-war planning and critical evaluation of past amphibious assaults, laid the ground work for a coherent approach to offensive amphibious warfare, capable of adaptation and criticism. Significant attention will be paid to the Tentative Manual for Landing Operations, published by the U.S. Marine Corps in 1934. Although failing to reference Gallipoli specifically, the Tentative Manual's comprehensive definition of naval gunfire support builds upon numerous lessons extracted from the 1915 campaign.
\end{abstract}

\section{Introduction}

The increasing industrialization of warfare during the twentieth century witnessed a significant uptick in the complexities of amphibious operations. Modern amphibious warfare traces its origin to an ill-conceived and poorly implemented amphibious assault on the rocky boundary between the European and Asian continents, less than one year after the start of the Great War. Following the disaster at Gallipoli in 1915, the British, despite their long tradition of naval dominance, dismissed amphibious operations as a viable form of warfare in the modern conflict. British "tactical pundits" during the remainder of World War I, and throughout the inter-war years that followed, firmly believed "that amphibious assaults could not prevail against prepared defenses armed with machine guns and artillery." ${ }^{11}$ At the crux of this belief sat the issue of naval gunfire support; an integral facet of amphibious operations that remained a

"Military Historian, Norwich University Alumni, USA.

1. Allan R. Millett, "Assault from the Sea: The Development of Amphibious Warfare between the Wars: The American, British, and Japanese Experiences," in In the Interwar Period, ed. Williamson Murray and Allan R. Millett (Cambridge: Cambridge University Press, 1996), 52-53. 
dominant focus during the inter-war years, the amphibious campaigns of the next World War, and a haunting reminder of the horrors on the Hellespont.

Across the Atlantic and on the other side of the world, American and Japanese military leaders were not as dismissive of amphibious warfare as their British counterparts. Separated by the vast Pacific Ocean, dotted with seemingly innumerable atolls and archipelagos, planning for amphibious operations took center stage as both sides realized this form of warfare was to dominate any future conflict between their nations. Although caught by surprise in December of 1941, the United States had spent considerable time, energy, and resources during the inter-war period developing and refining strategies for offensive and defensive operations in a hypothetical war in the Pacific. The U.S. Marine Corps in particular focused on preparations for carrying out opposed landings, publishing the Tentative Manual for Landing Operations in 1934, outlining the use of U.S. Marine Corps units to seize islands in the Pacific to be used as steppingstones as the U.S. military took the conflict all the way to Japan. ${ }^{2}$ The lessons of Gallipoli, especially those related to the use of naval gunfire support, were key pieces of American pre-war planning. Yet they did undergo considerable revision once the war began. This study will utilize the 1943 Battle of Tarawa as a lens to examine and evaluate the influence of the ill-fated Gallipoli campaign of 1915 upon U.S. Marine Corps inter-war development of naval gunfire support doctrine within amphibious warfare planning and the effectiveness of those plans in combat operations during Operation GALVANIC.

Significant secondary source material utilized in this study is drawn from a variety of works authored by the late Colonel Joseph H. Alexander, USMC (Ret.). Alexander's magnum opus, Utmost Savagery: The Three Days of Tarawa, originally published in 1995, solidified his position as the "preeminent living authority" on the subject. ${ }^{3}$ Marine Corps History and Museums director, Brigadier General Edwin H. Simmons, USMC (Ret.), described Alexander's study as "quite probably the most significant book...on Tarawa since Robert Sherrod wrote Tarawa: The Story of a Battle." 4 Research and writing concerning Tarawa benefited in the 1990s from never-before available information. Translated volumes of the Japanese history of the conflict, declassified U.S. military documents, and verified accounts of veterans sharing their experiences for the first time, offered opportunities to re-evaluate established opinions of the engagement. More broadly, re-evaluation deepens our understanding of the Tarawa landings in the larger context of the war in the Pacific, opening doors for doctrinal lessons applicable for today, as far-flung island strongholds and littoral threat

2. David J. Ulbrich, "The U.S. Marine Corps, Amphibious Capabilities, and Preparations for War with Japan," Marine Corps University Journal 6, no. 1 (Spring 2015), 81, 82.

3. Joseph H. Alexander, Utmost Savagery: The Three Days of Tarawa (Annapolis: Naval Institute Press, 1995), xiv.

4. Ibid., xiii. 
environments begin to demand attention in the foreign policy arena. This study applies this methodology a step further by cross-examining more recent examples from this topic's historiography against the primary source evidence, in order to provide a fresh and accurate understanding of the Marine Corps' development of naval gunfire doctrine from the inter-war years to the opening salvo against a fortified island stronghold such as Tarawa.

During my own examination of the more recent works on Tarawa, the theme of naval gunfire support within pre-war Marine Corps planning and its implementation at Tarawa began to take shape. Older sources addressing Tarawa, such as Jeter Isely and Philip Crowl's comprehensive study of Marine Corps amphibious warfare in the Pacific, downplayed the shortcomings of naval gunfire support at Tarawa; a view this author does not believe is sufficiently supported by primary source evidence, nor pre- and contemporary-World War II understanding of the Gallipoli campaign.

This study begins with a brief overview of the amphibious assault on Gallipoli, followed by an assessment of the effectiveness of British naval gunfire support during the landing. Contextual understanding for this study begins with a discussion of the atmosphere surrounding U.S. military and Marine Corps planning for, and anticipation of, a future conflict with Japan dispersed across the expanse of the Pacific Ocean. Focus transitions to the conception of the Tentative Manual for Landing Operations and in-depth study of the Tentative Manual's tenets concerning proper naval gunfire doctrine. Primary source material provides a detailed description of Tarawa, specifically Betio island, in addition to the Marine Corps' preparation for assault, difficulties imposed by the environment, and the planned employment and tasks of naval gunfire support. Discussion of the shortcomings of naval gunfire during the assault on Betio is wound throughout a broader discussion seeking clarity between the theoretical plans for naval gunfire support versus implementation and effectiveness in reality. This body of the study transitions to an overall understanding of the lessons naval gunfire use at Tarawa provided for subsequent Pacific campaigns and the validity of American amphibious warfare doctrine.

\section{The British Assault at Gallipoli}

British, French, and ANZAC (Australian and New Zealand Army Corps) forces were at as much the mercy of poor leadership as they were to the multitude of difficulties imposed on them by the rugged geography of the Gallipoli peninsula and the dogged Turkish defenses. The amphibious assault on Gallipoli began on 25 April 1915 with simultaneous landings at seven individual locations. ANZAC troops stormed "Z" beach, north of Gaba Tepe, the furthest 
north of the Allied landings zones, with Hill 971 as their objective. ${ }^{5}$ To the south at Cape Helles, troops of the British $29^{\text {th }}$ Infantry Division assaulted " $Y$," " $X$," "W," "V," and "S" beaches, while a small contingent of French troops launched a diversionary assault on the Asian coast of the Dardanelles Strait at Kum Kale. ${ }^{6}$ Aside from a few reconnaissance trips along the peninsula, Sir Ian Hamilton, commander of the ground forces for the campaign, had only "a 1908 sheet taken from a general survey of Turkey" with which to base his knowledge of the terrain. ${ }^{7}$ Other important landing details were equally vague. The operational order for crews transporting troops toward " $Y$ " beach instructed them that they were "to convoy the troops almost directly ashore 'till they felt the bottom" at which time debarkation could take place. ${ }^{8}$ Incredibly, the British had failed to conceive contingency plans for localized success, let alone failures. Momentary successes, such as the British rapid penetration of Turkish defenses near " $\mathrm{X}$ " Beach, slowly smoldered away and extinguished hopes of tactical opportunity. ${ }^{9}$

Most appalling was the inability, and at times unwillingness, of the British to properly employ naval gunfire support. The lack of which proved singularly detrimental to the outcome of the assault, indeed the campaign as a whole. An ironic issue considering the Royal Navy had an ample number of ships present mounting large-caliber guns capable of supporting the assault forces. Apart from " $Y$ " beach, British and French warships provided thirty minutes of gunfire support, after which time, fire was to be lifted inland toward the Turkish artillery batteries, "'the first objective of naval fire."'10 The result was that the amphibious forces assaulting the shallow beaches and steep cliffs did so without the benefit of supporting fire. ${ }^{11}$ Royal Navy command suffered from a case of strategic paralysis. Historian Theodore Gatchel explains, "the ultimate purpose of military operations on the Peninsula was to get the fleet through to overawe Constantinople," thereby threatening the Ottoman capital with sea-borne destruction and force the aged member of the Central Powers to capitulate. ${ }^{12}$ Over-emphasis on the end goal resulted in tactical and operational decisions concerning the means that bordered on absurdity. Having "no desire to reach their destination with depleted magazines," capital ships were limited to "only 20 rounds per gun as a maximum" for fire missions in support of the landing forces. ${ }^{13}$

5. Robin Prior, Gallipoli: The End of the Myth (New Haven: Yale University Press, 2009), 90.
6. Ibid.
7. Ibid., 78.
8. Ibid., 91.
9. Ibid., 99.
10. Ibid., 91.
11. Ibid.

12. Ibid., 91; Theodore L. Gatchel, At the Water's Edge: Defending against the Modern Amphibious Assault (Annapolis: Naval Institute Press, 1996), 11.

13. Prior, Gallipoli, 91-92 (author's emphasis). 
Perhaps more astonishing was one British prediction that the Queen Elizabeth, at the time the world's most powerful battleship, "could demolish all 24 Dardanelles forts with about 10 shells for each fort - a total of just $240 \times 15$-inch shells." 14 This naively optimistic assumption ignores that fact that the first high explosive shell to reach its target disrupted so much dust that target evaluation, as well as subsequent range finding and adjustment, were nearly impossible. ${ }^{15}$

Further compounding the issue of naval gunfire support was a lack of basic gunnery understanding one assumed the world's most powerful navy had mastered. Despite instructions for the bombarding ships to use their fore and aft anchors to stabilize their main armament during firing, British commanders failed to consider the rocking that ensued as the anchors and the swift current in the Dardanelles Strait played a continuous tug-of-war. ${ }^{16}$ Additionally, the Royal Navy mistakenly believed warships could inflict on Turkish forts the kind of destruction wrought by German howitzers on the Belgian forts in 1914. The naval rifles of the Royal Navy fired at a flat trajectory, not at all the ideal angle for engaging a fort. ${ }^{17}$ The failure to use capital ships at Gallipoli was two-fold. Earlier attempts in February and March to rush the Dardanelles Strait using warships alone met with failure, leaving planners in London convinced of the need for a ground force to be landed and assault the Turkish fortifications directly. Yet, once the ground component was landed in April, the navy performed a minimal role; an embarrassing lack of inter-service coordination and cooperation in a so called "combined" operation. The Gallipoli debacle cast a long shadow for years thereafter, sowing doubt about the viability of amphibious warfare in an era when advances in military technology did not diminish the propensity of the defender to stymie assaults at the water's edge.

\section{The Genesis of U.S. Marine Corps Amphibious Doctrine}

A decade and a half later, the increasing possibility of Japanese expansion in the Pacific boiling over into general war, led the "staff and war colleges of the American armed forces" to give much "greater attention to instruction on

14. Ibid., 38.

15. Ibid., 101.

16. Ibid., 37.

17. Ibid., 39-40. Prior discusses the work of the Mitchell Committee which at the time of the Gallipoli campaign, had developed a scientific method for determining the number of shells required to destroy any given number of fortifications at varying ranges. Based on their calculations, Prior explains that a minimum of 20,000 shells were required to defeat the Turkish fortifications along the Dardanelles. None of the gun barrels on the warships available to the Royal Navy, including those on the new Queen Elizabeth, were capable of firing their share of those 20,000 rounds before bursting or needing to be re-bored. 
amphibious operations." 18 As a department of the Navy, the U.S. Marine Corps was saddled with the responsibility of protecting and seizing American holdings in the Pacific in peace and as well as in war. As a consequent of their status as a component of the Navy, the Marine Corps was left square in the sights of politicians seeking to curb unnecessary defense spending as economic constraints became more acute in the 1930s. Certain Army leaders "doubted the need for an independent marine corps" and it was only Congressional action that prevented the Corps from being absorbed into the Army. ${ }^{19}$ The Marine Corps began writing doctrine for amphibious operations in an attempt to stay the imminent possibility that their existence could be eliminated during government budget cuts, as well as address the looming potentiality of a trans-Pacific armed struggle against Imperial Japan. ${ }^{20}$ Within the Marine Corps hierarchy, there existed a cadre of officers who refused to believe the industrialization of warfare relegated amphibious operations to the past. They "remained confident that such beaches as those at Gallipoli could be seized and secured." 21 Through extensive examination of the failures at Gallipoli, the Marine Corps gained increasing confidence for the prospect of future amphibious operations, including the importance of naval gunfire support, identified as one of six "functional areas" integral to the successful landing of forces against a defended shore.22 Much of their research and planning rested upon the prophetic teachings of Lieutenant Colonel Earl H. "Pete" Ellis who foretold the scenario to beset the U.S. military in the Pacific during the first half of the 1940s. According to Ellis, the Marine Corps was naturally endowed with the skills necessary to prosecute this emerging form of modern warfare. In "Advanced Base Operations in Micronesia," Ellis claimed that,

to effect a landing under the sea and shore conditions obtaining and in the face of enemy resistance requires careful training and preparation, to say the least; and this along Marine Corps lines. It is not enough that the troops be skilled infantry men or artillery men of high morale: they must be skilled water men and jungle men who know it can be done - Marines with Marine training. ${ }^{23}$

In the years following the Great War, Ellis declared that in a future conflict in the Pacific, Japanese island strongholds not only needed to be "seized forcibly,"

18. Millett, “The Development of Amphibious Warfare between the Wars," 74.

19. Ibid., 72 .

20. Ibid., 75 .

21. Jeter A. Isely and Philip A. Crowl, The U.S. Marines and Amphibious War: Its Theory, and Its Practice in the Pacific (Princeton: Princeton University Press, 1951), 5.

22. Joseph H. Alexander, Storm Landings: Epic Amphibious Battles in the Central Pacific (Annapolis: Naval Institute Press, 1997), 13.

23. Fleet Marine Force Reference Publication (FMFRP) 12-46, Advanced Base Operations in Micronesia (Quantico: Marine Corps Combat Development Command, 1992), 41. 
but also the grand strategy of the conflict necessitated "island hopping." ${ }^{24} \mathrm{~A}$ task, Ellis affirmed, especially suited for the Marine Corps, but one, he warned, the Corps was dangerously unprepared for..$^{25}$

\section{A Coherent Doctrine for Naval Gunfire Support}

The Tentative Manual for Landing Operations, the most important piece of doctrine to emerge during this time, was published in June 1934, following a suspension of classes at the Marine Corps Schools to provide faculty and students the time to compile their views and lessons drawn from earlier amphibious operations. ${ }^{26}$ Although the horrors of Gallipoli remained present even in the minds of American military planners, "American Marines postulated that careful planning, adequate training, and proper equipment could overcome the tactical advantages enjoyed by an enemy defending a shoreline." 27 The Tentative Manual for Landing Operations identified and individually addressed the multitude of complex components within amphibious operations, all the while conveying the understanding of the importance each moving part has within the broader issue at hand. Even a cursory examination of the Tentative Manual's table of contents, reveals a fundamental understanding of the "combined" nature of amphibious operations in addition to the uniqueness and necessity of individual factors, from "Protection Against Chemical Agents" to "Troop Antiaircraft Defense." 28

Naval gunfire support is addressed in the Tentative Manual's second chapter in which its every aspect is discussed, from fleet organization to proper gun elevation. ${ }^{29}$ Without specifically mentioning Gallipoli, the Tentative Manual extracted numerous lessons from that ill-fated campaign. Naval fire support is divided into four categories: beach fire, support fire, interdiction fire, and counterbattery fire. ${ }^{30}$ Contrary to the definition-lacking approach employed by the Royal Navy in 1915, the Tentative Manual acknowledges the fluidity of amphibious operations and need for supporting arms, in this case warships, to keep pace with the changing threat environment. ${ }^{31}$ Fire support from warships "must be prepared in advance in order to coordinate this fire with the movement of the attacking troops." ${ }^{2}$ It was required that this coordination be maintained throughout the totality of the operation. ${ }^{33}$ The Tentative Manual does not cut any

\footnotetext{
24. Alexander, Storm Landings, 9.

25. Ibid., 10.

26. Ulbrich, "Amphibious Capabilities," 83.

27. Ibid.

28. Tentative Manual for Landing Operations (Quantico: Marine Corps Schools, 1934), 3.

29. Ibid., 42, 56.

30. Ibid., 43.

31. Ibid., 56.

32. Ibid.

33. Ibid.
} 
corners reinforcing the relationship between naval gunfire support and the delivery of assault troops to their proper landing locations. "The effectiveness of artillery preparation in an attack," explains the Tentative Manual, "decreases in direct proportion to the increases in time required for the assaulting troops to gain their positions after the fire lifts." 34 In other words, the delay between the lifting of naval gunfire, in order to prevent friendly fire casualties, and the moment the landing forces make their assault, must be as short as safety will allow. Safety is ensured with a fire schedule synchronized between all participating forces, ideally guaranteeing coordination and communication..$^{35}$

British failure at Gallipoli was due in part because British commanders expected the situation to conform to the naval preparations they already decided in their minds was going to carry the day. Differentiation between types of supporting fires did not exist, leaving the British and Commonwealth troops "at the mercy of obstacles, machine guns, and other rapid fire weapons." 36 Precisely the situation the Tentative Manual warns will take place on the landing beaches if "the ship's guns have not properly done their part." 37 Seeking to avoid a repeat of Gallipoli on a Pacific atoll and allowing the facts on the ground to dictate the type of response required, the Tentative Manual asserts that the "kind and amount of beach fire required for a particular landing [varies] according to the circumstances [of] the particular operation." 38

Additionally, the Tentative Manual, does not impose limitations on the amount of ammunition required for fire missions. Fire support commanders are to ensure that "a careful estimate [is] made of [the] ammunition that will be required, and ample provision [is] made for supply." 39 Tables illustrating the trajectory of fired ordnances of various calibers, crater sizes corresponding to ordnance type, shell burst diameter in regards to troop proximity, and beach topography not only enhance the doctrine put forth in the Tentative Manual, but also provide leaders at all levels of command invaluable information, should the United States find itself engaged in hostilities in the Pacific. ${ }^{40}$

Revisions to the Tentative Manual continued throughout the 1930s when in 1938, the U.S. Navy published Landing Operations Doctrine (Fleet Training Publication (FTP) 167), a merger adding "broad strategic and naval perspectives to the Marines' tactical and operational focuses." ${ }^{41}$ Under the guidance of Marine Corps Schools commandant General Thomas Holcomb, the Tentative Manual underwent modifications in order to become compliant with the U.S. Navy's

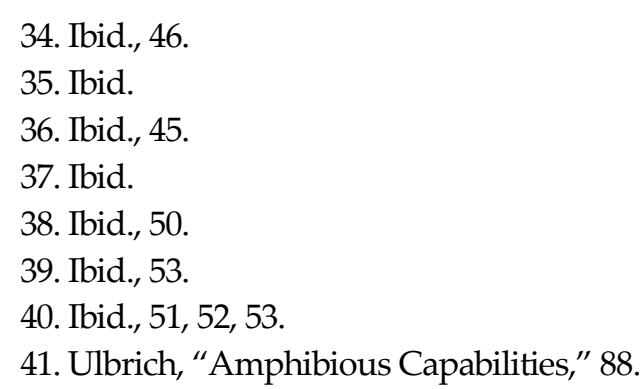


requirements. ${ }^{42}$ Following official adoption, FTP-167 remained at the core of American amphibious operations throughout the Pacific War. ${ }^{43}$ Chapter five of FTP-167 begins with the affirmation that "effective naval gunfire may be the critical factor which determines success or failure." 44 The "requirements of the infantry in an amphibious operation are essentially the same as the requirements in normal land warfare." ${ }^{45}$ In verbiage transcending military and naval schools of thought, FTP-167 equates the role of naval gunfire support with the responsibility of artillery in a land-based battle or campaign, adding the warning "...it will be rare in landings against opposition that [land-based] artillery will be able entirely to relieve naval fire support groups during D-day." 46 The growing understanding of amphibious warfare's ever-evolving character is exemplified through the division of D-day into three separate phases, pairing required fires and targets with the activity of the landing force at each phase of the assault. ${ }^{47}$ Together, these tentative guidelines and instructions for the incorporation and coordination of naval gunfire support received their baptism by fire in the late fall of 1943, as U.S. forces sought to wrest the Gilbert Islands from Japanese control and begin the long-awaited offensive across the central Pacific.

\section{The U.S. Marine Assault at Tarawa Atoll}

\section{Surmounting Betio's Challenges}

The focal point of the Battle of Tarawa (Operation GALVANIC) was the tiny island of Betio located on the southwestern tip of the triangular-shaped Tarawa atoll. Only four thousand yards long by six hundred yards wide, "Betio is smaller than New York City's Central Park." Nevertheless, the island presented numerous challenges to the American forces preparing to assault this heavily fortified piece of coral. ${ }^{48}$ Any brief inspection of Betio reveals that its terrain, or rather the lack there of, favored its Japanese defenders. After examining preliminary intelligence, Colonel Merrill A. Edson, chief of staff for the $2^{\text {nd }}$ Marine Division commented that, "'every place on the island can be covered by direct

42. Ibid.

43. Ibid., 83,84 .

44. Landing Operations Doctrine F.T.P. 167 (Washington D.C.: Office of Naval Operations Division of Fleet Training, 1938), 111, https://www.history.navy.mil/research/ library/online-reading-room/title-list-alphabetically/1/landing-operations-doctrine-usn-ftp167.html.

45. Ibid., 114.

46. Ibid., 115.

47. Ibid., 134, 135-136, 141-142.

48. Gatchel, At the Water's Edge, 121-122. 
rifle and machine gun fire.'" 49 Betio's limited size precluded a mobile defense. ${ }^{50}$ Therefore the Japanese defenders sought to defeat the Americans at the water's edge with a lethal assortment of large caliber, turret-mounted naval guns, mortars, and "an abundance of $7.7 \mathrm{~mm}$ light machine guns," spread throughout nearly five hundred individual bunkers, forcing the assaulting U.S. Marines to attack each one individually. ${ }^{51}$ Despite the difficulties of the terrain, Rear Admiral Keiji Shibasaki, tasked with the Japanese defense of Betio, intended to launch a counter-attack should American forces secure a foothold. During the afternoon of D-Day, Shibasaki and his entire staff died while attempting to relocate their command post to a location along the atoll's south coast. Victim of a large-caliber shell, Shibasaki's death eliminated any chance of a coherent Japanese counterattack against the burgeoning American onslaught. ${ }^{52}$

According to a December 1943 memorandum written by Lieutenant General A. A. Vandegrift, who commanded the $1^{\text {st }}$ Marine Division on Guadalcanal, Betio's size harbored two additional and particularly lethal consequences, each influencing the high casualties sustained by the U.S. Marine Corps during the assault. The Japanese, Vandegrift explains, could

readily diagnose the point of attack, and due to the small distances involved, [could] readily concentrate [their] forces against any landing attempt, and concentrate practically all the fire of [their] artillery against the attack without being forced to the time consuming effort of displacing [their] artillery forward..$^{53}$

Complicating the situation was Betio's extensive reef, eight hundred yards wide in some locations. This required the attacking Marines "to disembark from

49. Joseph H. Alexander, "Across the Reef: The Marine Assault of Tarawa, Part I" in Marines in World War II Commemorative Series, (United States Government, 1993), 3.

50. For further discussion on the relationship between geography and history, readers should examine Samuel Kinser's "Annaliste Paradigm? The Geohistorical Structuralism of Fernand Braudel," American Historical Review 86, no. 1 (February 1981): 63-105. Kinser delves into Braudel's argument, outlined in The Mediterranean and the Mediterranean World in the Age of Phillip II, for geographical determinism and Braudel's understanding that geography is not simply a painted canvas hung behind the stage of human history providing a general setting. Braudel understood, explains Kinser, geography and human action as two forces simultaneously shaping, and being shaped by, one another. Geography is by no means the only lens through which to study past events, however terrain is not merely something to be overcome; its inherent advantages and disadvantages fundamentally affect decisions, particularly military operations.

51. Alexander, "Across the Reef: The Marine Assault of Tarawa, Part I," 3; Gatchel, At the Water's Edge, 124.

52. Alexander, Utmost Savagery, 147-148, 151.

53. A. A. Vandegrift to David I. Walsh, 15 December 1943, Box 2, Alexander A. Vandegrift Papers, World War II Collection, Gilberts and Tarawa, Marine Corps University Archives, Quantico, VA. 
landing craft some distance off shore and wade in against the hostile fire." 54 Unable to seek protection in foxholes or behind obstacles and transported in lightly armed and armored LVTs (Landing Vehicle Tracked), it was imperative that naval fire support find its mark during preliminary bombardment. Then as the Marines' onshore operations started, the guns needed to exercise flexibility in fire missions.

As stated in an October $19432^{\text {nd }}$ Marine Division situation report, outlining potential amphibious offensive action in the Gilberts, the U.S. Navy had at its disposal three battleships, five cruisers, and ten destroyers for providing supporting fires for the Tarawa landings scheduled for November. ${ }^{55}$ Intelligence gathered regarding Japanese defenses, as well as the island itself, bluntly concluded that "the topography and hydrography of the area definitely favor the enemy." However, overly optimistic Marines also "expected that naval gunfire will neutralize or destroy the majority of" Japanese weapons and defensive positions "prior to H-hour." 56 The report estimates "that the average superiority of our [American] armament over that of the enemy, after naval gunfire lifts, is approximately...2.0:1.0." 57 This was a peculiar conclusion considering that the previous page of the report cautions those in the initial assault waves that the $75 \mathrm{~mm}, 105 \mathrm{~mm}$, and anti-aircraft battalions attached to the division will not be landed until a perimeter around the beachhead has been secured beyond the range of enemy machine guns and small arms. ${ }^{58}$ Seeking to maintain surprise, especially at the tactical level, planning called for the majority of naval gunfire to "be delivered primarily on D-day," with some naval commanders believing the Marines to be hard pressed to find defenders once they arrived ashore. ${ }^{59}$

\section{Naval Bombardment at Betio and Lessons Learned}

Preliminary naval bombardment of Betio was impressive, "however, it did not materially destroy bunkers along beaches." 60 Consistent with after action reports following the amphibious landings by elements of the $27^{\text {th }}$ Infantry

54. Patrick L. McKiernan, "Tarawa: The Tide that Failed," in Assault from the Sea: Essays on the History of Amphibious Warfare, ed. Merrill L. Bartlett (Annapolis: Naval Institute Press, 2014), 212; A. A. Vandegrift to David I. Walsh, 15 December 1943, Alexander A. Vandegrift Papers.

55. Rpt, HQ, 2nd Mar Div, 5 Oct 1943, sub: Estimate of the Situation - Gilberts, Marine Corps Schools, Record Section, Box 2, World War II Collection, Gilberts and Tarawa, Marine Corps University Archives, Quantico, VA, 14.

56. Ibid., 7, 14.

57. Ibid., 14.

58. Ibid., 13.

59. McKiernan, "Tarawa: The Tide that Failed," 214.

60. Brief on Tarawa Operation, CINCUS Plans Division, Pacific Section, Records WWII Amphibious Operations 1941-1946, Box 8, RG 38, NACP, 1. 
Division at Makin atoll further north, Navy and Marine commanders recommended that during future assaults, "precision shooting and bombing [should be conducted] over a longer period prior to D-day, [with] all firing vessels moving in closer and closer (with the first wave) on D-day - firing precision point blank until H-hour - then continuing fire on each flank." ${ }^{\prime \prime 1} \mathrm{~A}$ January 1944 report from the Planning Division, Pacific Sector, CINCUS (Commander-in-Chief U.S. Fleet) advised that "naval gunfire preparations for two or three hours is not adequate. This preparation should begin several days prior to D day and should be designed both for destruction and for unrelenting harassing effect." ${ }^{62}$ Additionally, preliminary naval gunfire support should utilize "all possible supporting weapons with a view toward maximum destruction of enemy installations." 63 The report delves into exhaustive detail concerning proper naval gunfire support for future amphibious assaults, affirming "that preparation fires in GALVANIC should be taken as a minimum standard." 64

Attention must be given to the choice and definition of the word "destruction" to describe the type of naval gunfire required as outlined within the reports. Historians Jeter Isely and Philip Crowl explain that 'destructive fire' and 'neutralization fire' refer to two different types of naval fire support, yet naval bombardment plans for the assault on Betio requested both simultaneously. Neutralizing fire support "is obtained through a huge volume of explosives" and achieved through indiscriminate saturation of a particular area. ${ }^{65}$ Through directing fire into seemingly random locations at varying intervals, an attempt is made to prevent the enemy from correctly discerning the next target. ${ }^{66}$ Destructive fire on the other hand is deliberate; pinpointed at specific targets and areas of enemy resistance. The lack of clearly defined terms resulted in haphazard fire support during the bombardment phase at Betio; obtaining neither neutralization nor destruction of Japanese installations. In an ironic twist from British efforts at Gallipoli to conserve ammunition during bombardment, naval gunners sighting-in Betio fired shells too quickly, generating considerable "dust

61. Brief of Report of Amphibious Operations for the Capture of the Gilbert Islands, CINCUS Plans Division, Pacific Section, Records WWII Amphibious Operations 1941-46, Box 8, RG 38, NACP, 9,10.; Brief on Tarawa Operation, NACP, 1.

62. Brief of Report of Amphibious Operations for the Capture of the Gilbert Islands, NACP, 8.

63. Ibid., 8.

64. Ibid., 9. A detail this report addresses that is particularly interesting is the admonition that warships armed with 5 "/25 guns should not be paired with warships employing $5 " / 38$ guns. The differences in barrel length would affect velocity and the fall of shot, both vitally important for effective gunfire support.

65. Isely and Crowl, U.S. Marines and Amphibious War, 232.

66. Philip A. Crowl and Edmund G. Love, Seizure of the Gilberts and Marshalls, United States Army in World War II (Washington D.C.: U.S. Army Center of Military History, 1993), 160. 
and smoke and [converting] what should have been direct pinpointed fire into radar-controlled indirect area coverage." 67 Little could have been done in the moment to improve the results of naval gunfire support on D-Day at Betio. Insufficient time allotted for bombardment precluded gun crews from delivering effective, destructive fire. ${ }^{68}$ Ideally, precision, point blank fire during initial bombardment, together with transitioning that fire to the flanks as the Marines disembarked from assault craft, not only promised improved destruction of enemy resistance on shore, but further destroyed beach obstacles and detonated mines just ahead of the assault troops. ${ }^{69}$ The necessity in future amphibious operations of employing naval gunfire in a destructive manner, rather than to merely neutralize enemy positions, remained at the top of operational lessons learned from the fighting on Betio. ${ }^{70}$

Naval bombardment at Tarawa brought renewed focus upon the Tentative Manual's exhortation concerning sufficient supplies and types of ammunition. Rear Admiral Howard F. Kingman, the naval gunfire support commander for the Betio landings, advocated for larger inventories of armor-piercing shells. Fired from the proper trajectory, armor-piercing shells stood a higher chance of penetrating reinforced-concrete bunkers. ${ }^{71}$ The January 1944 CINCUS report discussed above, lists increasing the angle of shell trajectory and employing "direct points of aim in a target vicinity" as two of its top three recommendations derived from study of naval gunfire support at Tarawa. ${ }^{72}$

Recognized during the Tarawa landing was the inter-war understanding that as an amphibious assault progressed, the threat environment naval gunfire had to contend with evolved proportionally. However, at Tarawa, this doctrine was applied poorly with regard to the lifting of naval gunfire. As the Marines arrived at the reef and began disembarkation, the most vulnerable point of their assault, they did not have the benefit of sustained naval gunfire support.

This proved especially costly due to a rare astronomical and environmental phenomenon, not entirely understood until forty-four years after the assault. In 1987, Donald W. Olsen, professor of physics at Southwest Texas State University, published his findings of a study examining the relationship between the tides at Tarawa and the moon's monthly orbit. Olsen discovered that the day on which the assault on Betio occurred, 20 November, was one of only two days in 1943 "when the moon's apogee" - the farthest distance of the moon from earth during its monthly orbit - "coincided with a neap tide" - which occurs during the

67. Isely and Crowl, U.S. Marines and Amphibious War, 232-233.

68. Crowl and Love, Seizure of the Gilberts and Marshalls, 160.

69. Isely and Crowl, U.S. Marines and Amphibious War, 233.

70. Allan R. Millett, In Many a Strife: General Gerald C. Thomas and the U.S. Marine Corps 1917-1956 (Annapolis: Naval Institute Press, 1993), 227.

71. Isely and Crowl, U.S. Marines and Amphibious War, 233.

72. Brief of Report of Amphibious Operations for the Capture of the Gilbert Islands, NACP, 9. 
moon's first or last quarter where there is the least change between high and low tide. ${ }^{73}$ In other words, the tidal range at Betio on D-Day was a matter of inches not feet; the lowest and least changing tide during the entire year. ${ }^{74}$ One after action report noted specifically that a forty-five minute delay in H-hour, "caused some lightening of the bombardment which should have reached its greatest intensity while the reef was being crossed."75 In fact, the last twenty-five minutes of the assault run, witnessed a "near-total curtailment of naval gunfire," allowing the Japanese, dazed but undaunted, to shift reinforcements to the beaches on the north side of the island that they now understood to be the primary landing zones. ${ }^{76}$ Without the suppression of Japanese defenses, the first wave of Marines arrived bloodied and disorganized. The second and third waves arrived to find the beaches littered with the dead, dying, and dumfounded who were prevented from maneuvering off the beach due to a sea wall and an increasing storm of lead from small and large caliber weapons. Indeed, most of the casualties sustained by the Marines occurred as they attempted to wade across the reef. ${ }^{77}$ With emphasis, the report mentioned above affirms the truth revealed on the cliffs of Gallipoli; troops alone cannot destroy bunkers, let alone close with them, without sustained and accurate fire from supporting warships. ${ }^{78}$

Following the assault, a deeper understanding emerged of the inextricable relationship between naval gunfire support and the necessity of maintaining momentum during an amphibious assault. The lack of destruction wrought by initial bombardment, compounded by curtailment at the most vital moment of landing, greatly impeded the effort of the first wave of Marines to gain a substantial foothold. Historians Jeter Isely and Philip Crowl assigned blame for the loss of momentum during the landing upon the "lack of amphibian tractors...or on the absence of sufficient water over the reef to float landing craft."79 Unfortunately, Isely and Crowl failed to extended sufficient blame over the role inconsistent naval gunfire support exercised upon the momentum of the assault. The Tarawa landings demonstrated the imperative need for naval gunfire, both before and during an assault against a defended island, to be lengthy, thorough, and deliberate. ${ }^{80}$

73. Alexander, Storm Landings, 53; Alexander, Utmost Savagery, 76.

74. Alexander, Storm Landings, 53.

75. Brief on Tarawa Operation, NACP, 1.

76. Alexander, "Across the Reef: The Marine Assault of Tarawa, Part I," 11.

77. Brief on Tarawa Operation, NACP, 1. In the run up to the reef, Marine gunners aboard the assaulting LVTs fired 10,000 rounds from their forward facing .50 caliber machine guns. Many died at their positions as the gun mounts lacked protective shield armor.

78. Brief on Tarawa Operation, NACP, 1-2.

79. Isely and Crowl, U.S. Marines and Amphibious War, 235.

80. Alexander, Utmost Savagery, 236. 


\section{Conclusion}

The carnage at Tarawa came as a terrible shock to the American public. The U.S. Marine Corps had suffered nearly as many casualties during seventy-six hours of fighting on Betio as they had absorbed during six months of fighting on Guadalcanal. ${ }^{81}$ In addition to the need for "revision[s] of naval gunfire...support doctrine," Marine commanders petitioned for the "accelerated production of amphibious tractors," as well as numerous other changes to pre-planning intelligence gathering and logistical oversight once amphibious assaults were underway. ${ }^{82}$ Close range naval gunfire support, such as what was provided by U.S. destroyers that entered Tarawa's shallow lagoon, was generally hailed as effective, but the timeframe and inaccuracy of preliminary bombardment left much to be desired. ${ }^{83}$

Rear Admiral Harry W. Hill, commander of the Southern Attack Force tasked with capture of Tarawa atoll, remarked following the battle that the landings on Betio, "provided the essential watershed between Gallipoli and the great amphibious landings of 1944-45." ${ }^{84}$ Tarawa served as a platform upon which inter-war ideas of amphibious operations were tested and their results adapted or modified in preparation for the amphibious assaults that were still to come, as the United States began the arduous advance toward Japan. American victory at Tarawa validated American amphibious warfare doctrine. ${ }^{85}$ Albeit in its infancy, inter-war planning and critical evaluation of past amphibious assaults, laid the ground work for a coherent approach to offensive amphibious warfare, capable of adaptation and criticism, upon which the United States crafted victory in the Pacific.

\section{Bibliography}

Alexander, Joseph H. "Across the Reef: The Marine Assault of Tarawa, Part I." In Marines in World War II Commemorative Series. United States Government, 1993.

Alexander, Joseph H. "Across the Reef: The Marine Assault of Tarawa, Part III." In Marines in World War II Commemorative Series. United States Government, 1993.

81. Alexander, "Across the Reef: The Marine Assault of Tarawa, Part III," 50. Total U.S. casualties at Tarawa numbered 3,407. Among the Marines who participated in the assault, approximately 19\% became casualties, however higher percentages existed among certain units. Of the estimated 4,836 Japanese troops defending Betio, 97\% were killed.

82. Millett, "The Development of Amphibious Warfare between the Wars," 172.; Alexander, "Across the Reef: The Marine Assault of Tarawa, Part III," 52.

83. Ibid., 51.

84. Alexander, Utmost Savagery, 236.

85. Millett, "The Development of Amphibious Warfare between the Wars," 52. 
Alexander, Joseph H. Storm Landings: Epic Amphibious Battles in the Central Pacific. Annapolis: Naval Institute Press, 1997.

Alexander, Joseph H. Utmost Savagery: The Three Days of Tarawa. Annapolis: Naval Institute Press, 1995.

Brief of Report of Amphibious Operations for the Capture of the Gilbert Islands. CINCUS Plans Division, Pacific Section, Records WWII Amphibious Operations 1941-46, Box 8, RG 38, NACP.

Brief on Tarawa Operation. CINCUS Plans Division, Pacific Section, Records WWII Amphibious Operations 1941-1946, Box 8, RG 38, NACP.

Crowl, Philip A., and Edmund G. Love. Seizure of the Gilberts and Marshalls. United States Army in World War II. Washington D.C.: U.S. Army Center of Military History, 1955.

Fleet Marine Force Reference Publication (FMFRP) 12-46, Advanced Base Operations in Micronesia. Quantico: Marine Corps Combat Development Command, 1992.

Gatchel, Theodore L. At the Water's Edge: Defending Against the Modern Amphibious Assault. Annapolis: Naval Institute Press, 1996.

Isely, Jeter A., and Philip A. Crowl. The U.S. Marines and Amphibious War: Its Theory, and Its Practice in the Pacific. Princeton: Princeton University Press, 1951.

Landing Operations Doctrine F.T.P. 167. Washington D.C.: Office of Naval Operations Division of Fleet Training, 1938, https://bit.ly/3el5a4a.

McKiernan, Patrick L. "Tarawa: The Tide that Failed." In Assault from the Sea: Essays on the History of Amphibious Warfare, edited by Merrill L. Bartlett, 210-218. Annapolis: Naval Institute Press, 2014.

Millett, Allan R. "Assault from the Sea: The Development of Amphibious Warfare between the Wars: The American, British, and Japanese Experiences." In In the Interwar Period, edited by Williamson Murray and Allan R. Millett, 50-95. Cambridge: Cambridge University Press, 1996.

Millett, Allan R. In Many a Strife: General Gerald C. Thomas and the U.S. Marine Corps 19171956. Annapolis: Naval Institute Press, 1993.

Prior, Robin. Gallipoli: The End of the Myth. New Haven: Yale University Press, 2009.

Rpt. HQ, $2^{\text {nd }}$ Mar Div. 5 Oct 1943. Sub: Estimate of the Situation - Gilberts. Marine Corps Schools, Record Section, Box 2, World War II Collection, Gilberts and Tarawa. Marine Corps University Archives, Quantico, VA.

Tentative Manual for Landing Operations. Quantico: Marine Corps Schools, 1934.

Ulbrich, David J. "The U.S. Marine Corps, Amphibious Capabilities, and Preparations for War with Japan," Marine Corps University Journal 6, no. 1 (Spring 2015): 70-105.

Vandegrift, A.A. Letter to David I. Walsh, 15 December 1943. Box 2, Alexander A. Vandegrift Papers, World War II Collection, Gilberts and Tarawa. Marine Corps University Archives, Quantico, VA. 